\title{
Cervical Cancer Clinical TNM Finding v7
}

National Cancer Institute

\section{Source}

National Cancer Institute. Cervical Cancer Clinical TNM Finding v7. NCI Thesaurus. Code C89478.

A clinical finding about one or more characteristics of cervical cancer, following the rules of the TNM AJCC V7 classification system. Because many patients are treated by radiation and never undergo surgical-pathologic staging, clinical staging provides uniformity and is preferred. (from AJCC 7th Ed.) 